\title{
Exercise after breast cancer treatment: current perspectives
}

This article was published in the following Dove Press journal:

Breast Cancer:Targets and Therapy

21 October 2015

Number of times this article has been viewed

\section{Christina M Dieli- \\ Conwright \\ Breanna Z Orozco}

Division of Biokinesiology and Physical Therapy, Women's Health and Exercise Laboratory, University of Southern California, Los Angeles, CA, USA
Correspondence: Christina M Dieli-

Conwright

Division of Biokinesiology and Physical

Therapy, Women's Health and Exercise Laboratory, University of Southern California, I540 E. Alcazar St., CHP I55, Los Angeles, CA 90033, USA

Email Cdieli@usc.edu

\begin{abstract}
Over the past 2 decades, great strides have been made in the field of exercise-oncology research, particularly with breast cancer. This area of research is particularly important since there are $>2.8$ million breast cancer survivors who are in need of an intervention that can offset treatment-related side effects. Noticeable reductions in physical fitness (ie, cardiopulmonary fitness and muscular strength), negative changes in body composition (ie, increase in body mass, decrease in lean body mass, and increase in fat mass), increased fatigue, depression, or anxiety are some of the common side effects of cancer treatments that negatively impact overall quality of life and increase the risk for the development of comorbidities. Exercise plays a vital role in improving cardiopulmonary function, psychological events, muscular strength, and endurance in breast cancer survivors, and thus should be considered as a key factor of lifestyle intervention to reverse negative treatment-related side effects. The purpose of this review is to address current perspectives on the benefits of aerobic and resistance exercise after breast cancer treatments. This review is focused on the well-established benefits of exercise on physical and emotional well-being, bone health, lymphedema management, and the postulated benefits of exercise on risk reduction for recurrence of breast cancer.
\end{abstract}

Keywords: breast cancer, exercise, physical well-being

\section{Introduction}

With $>2.8$ million breast cancer survivors (BCSs) in the United States, physical and emotional health-related factors pertaining to improved survivorship following cancer treatments are a growing concern. ${ }^{1}$ One such factor to consider during survivorship is the participation in exercise, which has been described as a modifiable risk factor for the prevention of primary and recurrent cancers. ${ }^{2,3}$ The field of exercise-oncology has grown exponentially over the past 35 years, with one of the earliest studies conducted in women with breast cancer undergoing chemotherapy in the late $1980 \mathrm{~s} .{ }^{4,5}$ Breast cancer has been a major focus of this area because epidemiological evidence reported that lifetime participation in physical activity may reduce the risk of breast cancer. ${ }^{6-8}$

Exercise plays a vital role in improving cardiopulmonary function, psychological events, muscular strength, and endurance in BCS., ${ }^{9}, 10$ These benefits are of particular importance since women diagnosed with breast cancer are estimated to decrease their physical activity levels by $11 \%$ following breast cancer diagnosis. ${ }^{11}$ Greater decreases in physical activity levels are observed in BCS who are treated with chemotherapy (50\%) and radiation (24\%) when compared to those who do not experience these treatment regimens. ${ }^{11}$ The highly noted benefits of exercise combined with the significant decreases in physical activity following diagnosis have established that the 
exercise after breast cancer treatment is an important area of research.

Discernible reductions in physical fitness (ie, cardiopulmonary fitness and muscular strength), negative changes in body composition (ie, increase in body mass, decrease in lean body mass, and increase in fat mass), increased fatigue, depression, or anxiety are some of the common side effects of cancer treatments that negatively impact the overall quality of life (QOL) and increase the risk for the development of comorbidities. ${ }^{12}$ These side effects may increase the likelihood for the development of secondary cancers as well as reduce survival rates. ${ }^{13}$ Thus, the benefits of exercise are imperative to achieve chemotherapy, radiation, and surgical treatments for breast cancer as these treatments can impair one's physical and mental capabilities.

The purpose of this review is to address current perspectives on the benefits of aerobic exercise (AE) and resistance exercise (RE) after breast cancer treatments. This review is focused on the established benefits of exercise on physical and emotional well-being, bone health, lymphedema management, and the postulated benefits of exercise on risk reduction for recurrence of breast cancer.

\section{Exercise and improved physical well-being}

The adverse effects of breast cancer treatments commonly impact the physical well-being of survivors. Some of these side effects include impaired cardiopulmonary fitness, reduced upper-extremity function and mobility, and elevated body weight. ${ }^{14,15}$ To address these side effects, the scientific community examined the effects of $\mathrm{AE}$ and $\mathrm{RE}$ regimens in BCS following cancer-related treatments (Table 1). Promising results of exercise intervention studies report that BCS who participate in AE or RE experience significant reductions in waist circumference and body fat, improved cardiorespiratory fitness, and increased lean body mass when compared to BCS who do not participate in exercise. ${ }^{16-18}$

In BCS, AE is an effective mean for improving cardiopulmonary fitness, often assessed by maximal oxygen consumption $\left(\mathrm{VO}_{2 \max }\right)$ and body composition (decreased percent body fat, increased lean body mass). ${ }^{9,16,19}$ For example, a 3-week, twice weekly, moderate intensity $\left(45 \%-65 \% \mathrm{VO}_{2 \max }\right)$ supervised AE program significantly improved $\mathrm{VO}_{2 \max }$ in $\mathrm{BCS} .^{20}$ Furthermore, BCS participating in an 8-week (two times per week) progressive (increased intensity by $5 \%$ heart rate reserve every 2 weeks) AE program showed a decrease in waist circumference compared to a sedentary control group. ${ }^{21}$ Of longer duration, Irwin et al found 6 months (three times per week) of moderate $(50 \%-80 \%$ maximal heart rate) gym and home-AE program increased lean body mass and decreased percent body fat in BCS. ${ }^{16}$ Overall, BCS who participate in regular (3-weekly sessions) AE ranging from as few as 3 weeks to 6 months may benefit from improvements in body composition and cardiopulmonary function. However, for sustained benefits of AE, BCS should consider long-term participation in AE.

RE effectively results in positive physical well-being adaptations including improvements in appendicular and whole-body lean mass, muscle strength, and aerobic capacity. ${ }^{22}$ Importantly, patients with cancer who participate in $\mathrm{RE}$ are at a $33 \%$ decreased risk of all-cause mortality, ${ }^{23}$ thus the inclusion of RE in an exercise program should not be overlooked. Gains in muscle strength may result in as few as 8 weeks in BCS. An 8-week whole-body progressive RE (50\%-80\% 1-repetition maximum [RM]) program demonstrated significant strength improvements in chest press, leg press, arm curls, and chair stand exercises in BCS. ${ }^{24}$ Of longer duration, Winter-Stone et al observed significant improvements in upper and lower body strength in BCS after 1 year of whole-body progressive RE (30\%-80\% 1-RM) compared to those who participated in a low impact, stretching program. ${ }^{25}$ Increasing lean body mass is important for overall muscular strength and balance and can improve in BCS following a 3-month whole-body supervised progressive RE (60\% 1-RM) program. ${ }^{22}$ In addition to strength and lean body mass gains, $\mathrm{RE}$ is effective at improving balance in BCS, as indicated following 24-month supervised progressive RE intervention. ${ }^{26}$ Overall, RE results in significant improvements in muscular strength, lean body mass, and balance in BCS. Therefore, the inclusion of an RE component, under the guidance of an exercise specialist, in an exercise intervention would be extremely beneficial for BCS to improve many aspects of physical well-being.

Researchers have manipulated the implementation of $\mathrm{AE}$ and $\mathrm{RE}$ by using a combined exercise program in $\mathrm{BCS}$, composed of both $\mathrm{AE}$ and RE modes. ${ }^{27-29}$ Combined exercise programs, ranging in duration from 3 to 8 months, can improve cardiopulmonary fitness, muscular strength, and balance..$^{27,29-30}$ Specifically, BCS participating in 5-6 months of combined exercise training have experienced greater decreases in central adiposity and waist-to-hip ratio, percent body fat, resting diastolic blood pressure, mean arterial pressure, and increases in fat-free mass and estimated $\mathrm{VO}_{2 \max }$, when compared to a sedentary control group. ${ }^{17,29}$ Thus, studies including combined exercise programs pose numerous benefits for BCS, which may outweigh participation in only one mode of exercise. 
Table I Effects of exercise on physical well-being

\begin{tabular}{|c|c|c|c|c|}
\hline Study & $\begin{array}{l}\text { Mode of exercise, } \\
\text { supervised vs home } \\
\text { based, group or individual }\end{array}$ & Duration & Intensity & Outcomes \\
\hline Irwin et $\mathrm{al}^{16}$ & $\begin{array}{l}\mathrm{AE} \text {, supervised and home } \\
\text { based, group and individual }\end{array}$ & $\begin{array}{l}6 \text { months; } 3 \times / \text { wk supervised; } \\
2 \times / \text { wk at home; } 15-30 \mathrm{~min} / \\
\text { session }\end{array}$ & $\begin{array}{l}\text { Moderate; } 50 \%-80 \% \text { maximal } \\
\text { heart rate }\end{array}$ & $\begin{array}{l}\downarrow \% \text { body fat, } \uparrow \text { lean body } \\
\text { mass }\end{array}$ \\
\hline Saarto et a $\left.\right|^{19}$ & $\begin{array}{l}\text { AE, supervised and home } \\
\text { based, individual }\end{array}$ & $\begin{array}{l}12 \text { months; I } \times / \text { wk supervised; } \\
2 \times / \text { wk home based }\end{array}$ & $\begin{array}{l}\text { Step aerobics: } 150-180 \text { jumps } \\
\text { ( } 10 \mathrm{~cm} \text { benches); pace at } \\
118 \mathrm{bpm}\end{array}$ & $\uparrow$ lean body mass \\
\hline Brdareski et $\mathrm{al}^{20}$ & $A E$, supervised, individual & 3 weeks; $2 \times /$ wk; $20 \mathrm{~min} / \mathrm{session}$ & $45 \%-65 \% \mathrm{VO}_{2 \max }$ & $\uparrow \mathrm{VO}_{2 \max }$ \\
\hline Guinan et $\mathrm{a}^{21}$ & $\begin{array}{l}\text { AE, supervised and home } \\
\text { based, individual }\end{array}$ & $\begin{array}{l}8 \text { weeks; } 2 \times / w k, 21-42 \mathrm{~min} / \\
\text { session }\end{array}$ & $40 \%-65 \%$ heart rate reserve & $\downarrow$ waist circumference \\
\hline Benton et $\mathrm{a}^{24}$ & RE, supervised, individual & 8 weeks, $2 \times /$ wk & $\begin{array}{l}\text { Whole-body progressive; } \\
10-12 \text { reps, three sets }\end{array}$ & $\uparrow$ muscular strength \\
\hline Winters-Stone et $\mathrm{a}^{25}$ & $\begin{array}{l}\text { RE, supervised and home } \\
\text { based, group and individual }\end{array}$ & $\begin{array}{l}\text { I year; } 2 \times / \text { wk supervised, } \\
\text { I } \times / \text { wk at home }\end{array}$ & $\begin{array}{l}\text { Whole-body progressive; } \\
\text { three sets at } 30 \%-80 \% \text { I-RM }\end{array}$ & $\uparrow$ muscular strength \\
\hline Cormie et $\mathrm{al}^{22}$ & RE, supervised, group & 3 months; $2 \times / w k$ & $\begin{array}{l}\text { Whole-body progressive; } \\
\text { 2-4 sets; I 2-8 RM load }\end{array}$ & $\uparrow$ lean body mass, \\
\hline Waltman et $\mathrm{a}^{26}$ & RE, supervised, individual & 24 months, $2 \times / w k$ & $\begin{array}{l}\text { Whole-body progressive; } \\
\text { two sets; } 8-12 \text { reps }\end{array}$ & $\begin{array}{l}\uparrow \text { muscular strength, } \\
\uparrow \text { balance }\end{array}$ \\
\hline Scott et al ${ }^{17}$ & $\begin{array}{l}\text { C with diet restriction, } \\
\text { supervised, individual }\end{array}$ & 6 months; $3 \times / \mathrm{wk}$ & $\begin{array}{l}\text { AE: } 30 \mathrm{~min} ; 65 \%-85 \% \max \mathrm{HR} \\
\text { RE: } 10-15 \text { min of resistance } \\
\text { band exercises }\end{array}$ & $\begin{array}{l}\downarrow \text { waist circumference, } \\
\downarrow \text { wait/hip ratio, } \downarrow \text { resting } \\
\text { diastolic } \mathrm{BP}, \uparrow \mathrm{VO}_{2 \max }\end{array}$ \\
\hline \multirow[t]{2}{*}{ Milne et $\mathrm{a}^{27}$} & C, supervised, individual & 12 weeks; $3 \times / w k$ & AE: $20 \mathrm{~min} / \mathrm{session}$ & $\begin{array}{l}\uparrow \text { aerobic fitness (aerobic } \\
\text { power index cycle test) }\end{array}$ \\
\hline & & & $\begin{array}{l}\text { RE: whole-body progressive, } \\
\text { two sets of } 10-15 \text { reps } \\
\text { (intensity not defined) }\end{array}$ & $\uparrow$ muscular strength \\
\hline Heim et $\mathrm{a}^{30}$ & C, supervised, group & 8 months; $2 \times /$ wk AE; $3 \times /$ wk RE & $\begin{array}{l}\text { AE: walking program; } 30 \text { min } \\
\text { (intensity not defined) } \\
\text { RE: intensity not defined }\end{array}$ & $\begin{array}{l}\uparrow \text { muscular strength, } \\
\uparrow \text { aerobic capacity }\end{array}$ \\
\hline Mills et $\mathrm{al}^{29}$ & C, supervised, individual & 5 months; $3 \times / w k$ & $\begin{array}{l}\text { AE: } 10-20 \text { min; } 40 \%-75 \% \\
V_{2 \max }, 8-12 \text { reps } \\
\text { RE: whole-body progressive; } \\
\text { I-3 sets at an RPE of } 3-7 \text { on } \\
\text { the modified Borg Scale }\end{array}$ & $\begin{array}{l}\downarrow \% \text { body fat, } \uparrow \text { fat-free } \\
\text { mass, } \uparrow \mathrm{VO}_{2 \max } \uparrow \text { mean } \\
\text { arterial pressure }\end{array}$ \\
\hline
\end{tabular}

Notes: $\uparrow$, increase; $\downarrow$, decrease.

Abbreviations: $\mathrm{AE}$, aerobic exercise; wk, week; min, minutes; $\mathrm{VO}_{2 \max }$, maximal oxygen consumption; RE, resistance exercise; RPE, rate of perceived exertion; bpm, beats per minute; reps, repetitions; RM, repetition maximum; max, maximal; HR, heart rate; C, combined aerobic and resistance exercise; BP, blood pressure.

The improvements in cardiopulmonary fitness and muscular strength derived from a combined exercise program may be vital toward maximizing improvements in physical well-being and overall survivorship among BCS.

\section{Exercise and improved emotional well-being}

Emotional well-being including QOL, fatigue, and psychological or psychosocial changes experienced by BCS following treatment is a major concern impacting survivorship. ${ }^{31}$ Compared to women without breast cancer, women with breast cancer experience significant declines in physical role function (the extent to which their physical ability interferes with work or other activities), bodily pain, social functioning, and emotional health. ${ }^{32,33}$ It is estimated that $~ 50 \%$ of women with breast cancer encounter depression, anxiety, or both upon a year following diagnosis. ${ }^{34} \mathrm{~A}$ large study including 1,993 BCS found that $66.1 \%$ of study participants reported moderate-to-severe fatigue and $24.9 \%$ reported moderateto-severe depression following treatment. ${ }^{35}$ In an effort to alleviate these adverse events, exercise intervention trials have been designed and tested in BCS.

Overall, AE improves emotional well-being in BCS (Table 2). BCS who participate in AE interventions ranging from 4 weeks to 6 months and intensities ranging from low (walking) to vigorous experience improvements in QOL, fatigue, social functioning, energy levels, and emotional distress when compared to sedentary controls. ${ }^{36-39}$ Importantly, 
Table 2 Effects of exercise on emotional well-being

\begin{tabular}{|c|c|c|c|c|}
\hline Study & $\begin{array}{l}\text { Mode of exercise, } \\
\text { supervised vs home } \\
\text { based, group or } \\
\text { individual }\end{array}$ & Duration & Intensity & Outcomes \\
\hline Cadmus et $\mathrm{al}^{37}$ & $\begin{array}{l}\mathrm{AE} \text {, supervised and home } \\
\text { based, individual }\end{array}$ & $\begin{array}{l}6 \text { months, } 5 \times / \mathrm{wk}, 30 \mathrm{~min} / \\
\text { session }\end{array}$ & $60 \%-80 \%$ of predicted max HR & $\begin{array}{l}\leftrightarrow \mathrm{QOL}, \uparrow \text { improved } \\
\text { social functioning }\end{array}$ \\
\hline Fillion et $\mathrm{a}^{38}$ & AE, supervised, group & 4 wks, I $1 \times / w k, I \mathrm{~h} /$ session & Walking (intensity not specified) & $\begin{array}{l}\downarrow \text { fatigue, } \uparrow \text { energy } \\
\text { level, } \downarrow \text { emotional } \\
\text { distress }\end{array}$ \\
\hline Courneya et al ${ }^{39}$ & $\mathrm{AE}$, supervised, individual & $\begin{array}{l}15 \mathrm{wks}, 3 \times / \mathrm{wks}, 15-45 \mathrm{~min} / \\
\text { session }\end{array}$ & $70 \%-75 \%$ of $\mathrm{VO}_{2 \max }$ & $\uparrow \mathrm{QOL}$ (FACT-B) \\
\hline Murtezani et al ${ }^{41}$ & $A E$, supervised, group & $\begin{array}{l}10 \text { wks, } 3 \times / \mathrm{wk}, 25-45 \mathrm{~min} / \\
\text { session }\end{array}$ & $50 \%-75 \% \max H R$ & $\uparrow \mathrm{QOL}(\mathrm{FACT}-\mathrm{G})$ \\
\hline Mehnert et $\mathrm{al}^{42}$ & $\mathrm{AE}$, supervised, individual & $10 \mathrm{wks}, 2 \times / \mathrm{wk}, 20 \mathrm{~min} / \mathrm{session}$ & $60 \%$ of $\mathrm{VO}_{2 \max }$ & $\begin{array}{l}\uparrow \text { psychosocial well- } \\
\text { being, } \uparrow \text { individual } \\
\text { body image }\end{array}$ \\
\hline Rogers et $\mathrm{al}^{43}$ & $\mathrm{AE}$, supervised, individual & $\begin{array}{l}3 \text { months, } 3 \times / \mathrm{wk}, 15-25 \mathrm{~min} / \\
\text { session }\end{array}$ & $40 \%-59 \%$ HR reserve & $\begin{array}{l}\uparrow \text { emotional well-being, } \\
\uparrow \text { functional well-being }\end{array}$ \\
\hline Benton et a $\left.\right|^{24}$ & RE, supervised, individual & $8 w k s, 2 \times / w k$ & $\begin{array}{l}\text { Whole-body progressive, three sets of } \\
8-12 \text { reps }\end{array}$ & $\uparrow \mathrm{QOL}$ \\
\hline Ohira et $\mathrm{a}^{44}$ & $\begin{array}{l}\text { RE, supervised and home } \\
\text { based, group }\end{array}$ & 6 months, $2 \times / w k$ & Whole-body (intensity not specified) & $\begin{array}{l}\uparrow \mathrm{QOL}, \leftrightarrow \text { depressive } \\
\text { symptom score }\end{array}$ \\
\hline Milne et $\mathrm{a}^{27}$ & C, supervised, individual & $12 \mathrm{wks}, 3 \times / \mathrm{wk}$ & $\begin{array}{l}\text { AE: } 20 \mathrm{~min} / \text { session } \\
\text { RE: whole-body progressive, two sets of } \\
\text { I0- } 15 \text { reps (intensity not defined) }\end{array}$ & $\uparrow \mathrm{QOL}$ \\
\hline \multirow[t]{2}{*}{ Heim et $\mathrm{a}^{30}$} & $\begin{array}{l}\text { C, supervised, group and } \\
\text { individual }\end{array}$ & 8 months; $2 \times /$ wk AE; $3 \times /$ wk RE & $\begin{array}{l}\text { AE: walking program; } 30 \mathrm{~min} \text { (intensity } \\
\text { not defined) }\end{array}$ & $\uparrow \mathrm{QOL}$ (FACT-G) \\
\hline & & & RE: intensity not defined & $\begin{array}{l}\downarrow \text { cancer-related } \\
\text { fatigue }\end{array}$ \\
\hline Hayes et $\mathrm{al}^{36}$ & $\begin{array}{l}\mathrm{C} \text {, supervised and home } \\
\text { based, individual }\end{array}$ & $\begin{array}{l}6 \mathrm{wks}, 4 \times / \mathrm{wk}, 45 \mathrm{~min} / \mathrm{session} \\
(2 \times / \mathrm{wk} \text { of } \mathrm{AE} \text { and } 2 \times / \mathrm{wk} \text { of } \mathrm{RE})\end{array}$ & $\begin{array}{l}\text { AE: low to moderate to high intensity } \\
\text { (specific } A E \text { and RE intensity not defined) }\end{array}$ & $\uparrow \mathrm{QOL} \downarrow$ fatigue \\
\hline Midtgaard et al ${ }^{40}$ & C, supervised, group & $6 \mathrm{wks}, 9 \mathrm{~h} / \mathrm{wk}$ total & $\begin{array}{l}\text { Intensity not defined (ball games, aerobics, } \\
\text { heavy resistance training, and cycling) }\end{array}$ & $\begin{array}{l}\uparrow \text { mental health, } \\
\uparrow \text { social functioning, } \\
\uparrow \text { emotional functioning }\end{array}$ \\
\hline Spector et $\mathrm{al}^{45}$ & $\begin{array}{l}\text { C, home based, } \\
\text { individual }\end{array}$ & 16 wks & $\begin{array}{l}\text { AE: } 150 \mathrm{~min} / \mathrm{wk} ; 40 \%-65 \% \text { HR reserve } \\
\text { RE: whole body; } 12-15 \text { reps }\end{array}$ & $\uparrow \mathrm{QOL}$ (FACT-B) \\
\hline Sprod et $\mathrm{a}^{46}$ & C, supervised, individual & $\begin{array}{l}3 \text { months or } 6 \text { months, } 2-3 \times 1 \\
\text { wk, } 60 \mathrm{~min} / \text { session }\end{array}$ & $\begin{array}{l}\text { AE: } 40 \mathrm{~min} ; 30 \%-55 \% \text { HR reserve } \\
\text { RE: whole-body, intensity not defined }\end{array}$ & $\downarrow$ fatigue \\
\hline
\end{tabular}

Notes: $\uparrow$, increase; $\downarrow$, decrease; $\leftrightarrow$, no change.

Abbreviations: AE, aerobic exercise; min, minutes; max, maximum; QOL, quality of life; h, hour; FACT-B, Functional Assessment of Cancer Therapy - Breast; FACT-G, Functional Assessment of Cancer Therapy - General; RE, resistance exercise; $\mathrm{VO}_{2 \text { max }}$, maximal oxygen consumption; HR, heart rate; $\mathrm{C}$, combined aerobic and resistance exercise; wk, week.

improvements in emotional well-being can result from as few as 6 weeks of AE. Midtgaard et al observed improved emotional functioning, social functioning, and mental health in BCS participating in a 6-week ( 9 hours/week) group AE program. ${ }^{40}$ A 10-week moderate intensity (50\%-75\% maximal heart rate) AE intervention resulted in significant improvements in QOL assessed by the Functional Assessment of Cancer Therapy General score in BCS when compared to a sedentary control group. ${ }^{41}$ Participation in $10-15$ weeks of moderate intensity (60\% $\left.\mathrm{VO}_{2} \max \right) \mathrm{AE}$ resulted in improvements in psychosocial, functional, emotional well-being, self-esteem, happiness, and individual body image. ${ }^{39,42,43}$ Accordingly, evidence strongly suggests that AE can target outcomes associated with overall emotional well-being in BCS, achievable within 6-24 weeks of regular exercise participation.

Although most commonly acknowledged for the established physical well-being adaptations, the effects of RE on emotional well-being have been investigated, minimally, posttreatment (Table 2). Participation in an 8-week progressive whole-body RE program resulted in significant improvements in QOL examined in younger (40-59 years) BCS. ${ }^{24}$ Additionally, BCS who participated in a 6-month progressive RE program reported improvements in the QOL. ${ }^{44}$ These investigations suggest that participation in RE can improve emotional well-being and may be beneficial when prescribing and implementing exercise programs for BCS. 
Similar to physical well-being adaptations, studies addressing the emotional well-being of BCS have used combined $\mathrm{AE}$ and $\mathrm{RE}$ programs. Combined programs ranging from 3 to 8 months lead to improvements in emotional wellbeing, including outcomes such as cancer-related fatigue, social well-being, and overall QOL. ${ }^{27,30}$ Specifically, a recent study found improvements in the breast cancer QOL questionnaire (Functional Assessment of Cancer Therapy - Breast) following the completion of a 16-week home-based combined exercise program. ${ }^{45}$ Further, significant fatigue reductions can occur in BCS following participation in the home-based combined exercise program. A 3-month or 6-month combined exercise program resulted in improvements in behavioral fatigue, sensory fatigue, affective fatigue, cognitive fatigue, and overall total fatigue in BCS. ${ }^{46}$ Thus, a combined RE and AE program should be considered to improve measures of emotional well-being, in particular, due to the strong effects on physical well-being that are elicited.

\section{Exercise and management of lymphedema}

Lymphedema secondary to breast cancer is a chronic debilitating condition and treatment-related sequelae, which is a substantial concern during survivorship. Lymphedema is caused by the disruption of the lymphatic system, leading to the accumulation of fluid in the interstitial space and clinically presented as swelling of the arm, shoulder, neck, or torso. ${ }^{47,48}$ Chronic swelling leads to soft tissue fibrosis and deposition of adipose tissue. Further, this increases the patients' risk of cellulitis causing additional damage to the lymphatic capillaries. ${ }^{49}$ Lymphedema is reported to develop in $\sim 20 \%$ of women following breast cancer treatments. ${ }^{50}$ However, the incidence rates vary based on the clinical definition. Importantly, lymphedema can develop years $(>2)$ after the initial cancer treatment, ${ }^{51-53}$ and irrespective of onset, lymphedema often causes emotional distress and compromised QOL. ${ }^{54,55}$ The recommended management of lymphedema by the National Lymphedema Network and the International Society of Lymphology is complete decongestive therapy, involving manual lymphatic drainage compression bandages, remedial active exercises, skin care, and patient education. ${ }^{56,57}$

Exercise may aid in the management of lymphedema with research limited to breast cancer-related lymphedema. ${ }^{58}$ Upper body exercise has traditionally been discouraged for BCS following axillary lymph node dissection and/or radiation. ${ }^{59}$ This advisement, largely unsubstantiated, arose from the belief that upper body exercise may initiate or worsen upper extremity lymphedema ${ }^{60,61}$ However, recent randomized controlled trials have challenged this belief and found no association between upper body exercise and the onset or worsening of breast cancer-related lymphedema. ${ }^{13,62}$ Furthermore, some forms of exercise, mainly progressive RE, is associated with less exacerbation of lymphedema-related symptoms in BCS. ${ }^{63,64}$ The largest exercise and lymphedema trial, the Physical Activity and Lymphedema Trial, demonstrated that supervised, slowly progressive RE performed twice weekly while wearing a compression garment is protective against lymphedema flare-ups. ${ }^{64}$ Importantly, a recent meta-analysis by Cheema et al examined the safety and efficacy of progressive RE on breast cancer-related lymphedema. ${ }^{65}$ Results from the meta-analysis, including nine studies, indicated that progressive RE actually reduced the risk of breast cancer-related lymphedema and did not worsen arm volume or symptom severity.

Despite the fact that strong evidence exists on the safety of progressive RE without an increase in risk of lymphedema for breast cancer patients, ${ }^{13}$ one should strongly consider safety precautions when initiating an $\mathrm{AE}$ or RE program. Although exercise, AE and/or RE, is safe, appropriate exercise programming should be executed. It is advised that exercise be initiated in a progressive manner such that the intensity, volume, and frequency are slowly progressed over time, under the supervision of a health care professional or certified cancer exercise specialist.

\section{Exercise and maintaining bone mineral density}

Various forms of breast cancer treatment can be detrimental to bone health, which would increase one's risk of osteoporosis and subsequent bone fractures. Adjuvant forms of therapy such as aromatase inhibitors are known to accelerate bone loss as a result of the estrogen deprivation effects of the treatment. ${ }^{66}$ Benefits of exercise are documented for bone mineral density (BMD) maintenance (assessed by dual-energy X-ray absorptiometry) in $\mathrm{BCS}^{67,68}$ and further warrants investigations, since treatment side effects such as chemotherapy-induced amenorrhea and chemotherapy itself may pose even greater losses of BMD in premenopausal BCS. ${ }^{69-71}$ These adverse effects have evoked the use of AE and RE as a prevention mechanism for deterring bone loss.

Although RE is traditionally utilized to prevent the loss of or maintenance of BMD, AE may also contribute to the maintenance of bone health (Table 3). For example, a 12-month supervised and home-based aerobic and circuit training program emphasizing in vigorous step aerobics (defined by the authors as $150-180$ jumps) and circuit training (defined 
Table 3 Effects of exercise on bone mineral density

\begin{tabular}{|c|c|c|c|c|}
\hline Study & $\begin{array}{l}\text { Mode of exercise, } \\
\text { supervised vs home } \\
\text { based, group or } \\
\text { individual }\end{array}$ & Duration & Intensity & Outcomes \\
\hline Saarto et al ${ }^{19}$ & $\begin{array}{l}\text { AE, supervised and home } \\
\text { based, individual }\end{array}$ & $\begin{array}{l}\text { I } 2 \text { months; I } \times / \text { wk supervised; } \\
2 \times / \text { wk home based }\end{array}$ & $\begin{array}{l}\text { Step aerobics: } 150-180 \text { jumps (I0 cm benches); } \\
\text { pace at II } 8 \text { bpm + circuit training (I50-I80 } \\
\text { steps with a } 40: 60 \text { s training/rest ratio) }\end{array}$ & $\begin{array}{l}\leftrightarrow \text { femoral } \\
\text { neck BMD }\end{array}$ \\
\hline Irwin et $\mathrm{al}^{16}$ & $\begin{array}{l}\mathrm{AE} \text {, supervised and home } \\
\text { based, group and individual }\end{array}$ & $\begin{array}{l}6 \text { months; } 3 \times / \text { wk supervised; } 2 \times 1 \\
\text { wk at home; } 15-30 \mathrm{~min} / \text { session }\end{array}$ & Moderate; $50 \%-80 \%$ maximal heart rate & $\begin{array}{l}\leftrightarrow \text { total } \\
\text { BMD }\end{array}$ \\
\hline Winter-Stone et $\mathrm{al}^{67}$ & $\begin{array}{l}\text { RE, supervised and home } \\
\text { based, individual }\end{array}$ & $\begin{array}{l}\text { I year, } 2 \times / \text { week supervised }+ \\
\text { I } \times / \text { wk home based }\end{array}$ & $\begin{array}{l}\text { Whole body; } 60 \%-70 \% \text { I-RM for } \mathrm{I}-3 \text { sets of } \\
8-12 \text { reps }\end{array}$ & $\begin{array}{l}\leftrightarrow \text { lumbar } \\
\text { spine BMD }\end{array}$ \\
\hline Dobek et al ${ }^{68}$ & $\begin{array}{l}\text { RE, supervised and home } \\
\text { based, individual }\end{array}$ & $\begin{array}{l}\text { I year, } 2 \times / \mathrm{wk}+\mathrm{I} \times / \mathrm{wk} \text { home } \\
\text { exercise }\end{array}$ & Whole body; two sets of $8-12$ reps & $\begin{array}{l}\leftrightarrow \text { lumbar } \\
\text { spine BMD }\end{array}$ \\
\hline Winter-Stone et $\mathrm{al}^{73}$ & $\begin{array}{l}\text { RE, supervised and home } \\
\text { based, individual }\end{array}$ & $\begin{array}{l}12 \text { months, } 2 \times / \text { wk }+1 \times / \text { wk at } \\
\text { home }\end{array}$ & $\begin{array}{l}\text { Body weight loaded vest at } 8-15 \text { reps of } \\
\text { two footed jumps }\end{array}$ & $\begin{array}{l}\leftrightarrow \text { lumbar } \\
\text { spine BMD }\end{array}$ \\
\hline
\end{tabular}

Notes: $\uparrow$, increase; $\downarrow$, decrease; $\leftrightarrow$, no change.

Abbreviations: AE, aerobic exercise; s, second; min, minutes; wk, week; BMD, bone mineral density; RE, resistance exercise; bpm, beats per minute; reps, replications.

as 150-180 steps with a 40:60 seconds of training:rest ratio), maintained BMD at the femoral neck when compared to a sedentary control group in BCS. ${ }^{19}$ Additional studies noted prevention of bone loss at the femoral neck and total body following participation in 6-12 months of moderate-to-vigorous AE. ${ }^{16,19}$ Overall, it may be plausible to prevent bone loss in $\mathrm{BCS}$ with a minimum of 6 months of participation in $\mathrm{AE}$.

$\mathrm{RE}$ has been used to maintain BMD in BCS (Table 3) due to the mechanical loading nature of RE that enhances osteoblastic activity in bone. ${ }^{72}$ For example, BCS who participated in 1-year supervised and home-based RE programs demonstrated lumbar spine BMD maintenance when compared to those who did not participate in RE. ${ }^{68,73}$ Additionally, supervised progressive RE and home-based RE were shown to preserve $\mathrm{BMD}$ at the lumbar spine, improve femoral neck $\mathrm{BMD}$, and total body BMD in BCS compared to those who did not participate in the intervention. ${ }^{67}$ Overall, RE is an effective method of exercise to maintain bone mass in BCS following cancer treatments and is important in the prevention of bone loss related to cancer and its associated treatments. To date, a review of literature revealed that there are no studies investigating the effects of a combined exercise program on $\mathrm{BMD}$ in BCS.

\section{Exercise and risk reduction for breast cancer recurrence}

One of the lifestyle factors most strongly and consistently associated with breast cancer recurrence is exercise. ${ }^{74}$ Numerous studies have associated moderate exercise with lower risk of breast cancer recurrence..$^{2,75-79}$ However, timing of exercise participation needs to be considered in relation to the cancer diagnosis. A meta-analysis of studies examining the timing of exercise and risk of recurrence in pre- and postmenopausal women found that exercise participation after diagnosis was associated with 34\% fewer deaths from breast cancer $(P<0.001), 41 \%$ fewer deaths from all causes $(P<0.001)$, and $24 \%$ reduction in recurrence. ${ }^{80}$ Epidemiologically, exercise is often assessed by intervieweradministered or self-administered questionnaires, involving patient recall of previous participation in exercise and commonly quantified using a range of metrics including hours per week, metabolic equivalent-hours per week, metabolic equivalent-hours per week per year, times per week. Overall, quantifying the exact volume of exercise to prevent disease recurrence is challenging; however, observational evidence indicates that $\geq 3$ hours of moderate-to-vigorous intensity $\mathrm{AE}$ per week may be beneficial in reducing mortality and morbidity in BCS. ${ }^{81}$

Perhaps one of the most profound clinical investigations studying this topic was that of Courneya et al who sought to examine disease-free survival (DFS) following AE (three times per week; $60 \%-80 \% \mathrm{VO}_{2 \max }$ ) or RE (three times per week; two sets of 8-12 replications; 60\%-70\% 1-RM) performed while undergoing chemotherapy. ${ }^{82}$ Overall, when compared to the control group, the exercise group experienced a higher 8-year DFS, overall survival, and distant DFS. The effect of exercise on DFS was potentially stronger for women who were overweight/obese, had stage II/III cancer, had estrogen receptorpositive tumors, had human epidermal growth factor receptor 2-positive tumors, received taxane-based chemotherapies, and completed $\geq 85 \%$ of their planned chemotherapy. Definitive Phase III trials are warranted to confirm these findings.

Potential mechanisms to mediate postmenopausal risk of recurrence through exercise participation are proposed 
to be driven by changes in body fat and inflammation ultimately affecting changes in specific biomarkers. Levels of insulin, estrogen, insulin-like growth factor-1, and markers of inflammation (eg, tumor necrosis factor [TNF]- $\alpha$ and interleukin[IL]-6) are potential biomarkers, which are influenced by exercise and may affect breast cancer recurrence. ${ }^{83}$ Evidence from cohort analyses and randomized trials has found the aforementioned biomarkers to be reduced with exercise, demonstrating that exercise can affect systemic biomarker levels in postmenopausal BCS. ${ }^{84-87}$ Overweight and obese BCS have elevated blood levels of estrogens and androgens ${ }^{88}$ and being overweight, obese, or sedentary is associated with elevated insulin and inflammatory markers including C-reactive protein, serum amyloid A, IL-6, IL-1, and TNF- $\alpha .{ }^{89}$ These biomarkers combined with elevated body fat may drive tumor growth, yet the exact mechanisms are unclear. Furthermore, these findings are not well-established in premenopausal patients with breast cancer, thus underlying mechanisms have not yet been determined to explain how exercise may impact the risk of recurrence in this population. Large randomized clinical trials have yet to determine specific exercise program parameters that will reduce the recurrence of breast cancer. These studies are challenging due to cost, large sample size needed, and duration of study to address appropriately what types of exercise may reduce the risk of recurrence.

An important consideration in examining the risk of breast cancer recurrence and posttreatment exercise is obesity. A large body of evidence exists to suggest that elevated BMI or body weight is associated with poorer breast cancer outcomes. ${ }^{80,90,91}$ To examine this association, Ibrahim and Al-Homaidth conducted a meta-analysis and reported that postdiagnosis exercise reduced the risk of breast cancer mortality only in women with a BMI $\geq 25 \mathrm{~kg} / \mathrm{m}^{2},{ }^{80}$ indicating that exercise may mediate prognosis through reducing body weight in women who were overweight or obese. This has been proposed only for postmenopausal women through mechanisms described previously. Future investigations are warranted to determine whether exercise affects tumor progression via the aforementioned mechanisms and with consideration of the influence of menopausal status and body weight.

Overall exercise prescription during survivorship is based on recommendations by the American College of Sports Medicine, American Cancer Society, and American Heart Association. These organizations along with the US Department of Health and Human Services recommend an overall volume of weekly activity of 150 minutes of moderateintensity $\mathrm{AE}$ or 75 minutes of vigorous-intensity $\mathrm{AE}$, or an equivalent combination and 2-3 weekly strength training sessions including exercises for major muscle groups. ${ }^{13,92}$ Although these exact recommendations are not prescribed specifically for risk reduction of recurrence, they are recommended for overall health and fitness improvements and maintaining a healthy body weight and should be considered when initiating or executing an exercise program for BCS.

\section{Future directions}

The exercise-oncology research pertaining to breast cancer has made significant strides over the years. As summarized in this review, exercise performed after breast cancer treatments can be effective at improving physical and emotional well-being, maintaining bone health, managing symptoms of lymphedema and perhaps even reducing the risk of lymphedema, and reducing the risk of breast cancer recurrence via reductions in body weight and associated inflammatory and endocrine biomarkers, as noted in previously published reviews. ${ }^{93,94}$ However, the potential to conduct future investigations is substantial due to the gaps in knowledge in posttreatment exercise and breast cancer research. This includes mechanisms to prevent or attenuate chronic and late effects of treatment (eg, peripheral neuropathy, cardiotoxicity, and bone mass declines); factors that predict response to exercise for prevention and attenuation of chronic and late effects; determining the optimal exercise prescription parameters (eg, does, timing, type, and intensity) to prevent or attenuate chronic and late effects; examining optimal exercise prescription parameters that influence tumor progression; and expanding the epidemiological evidence of the association between exercise participation and risk of cancer recurrence. ${ }^{94}$

Overall, when assessing the literature to prescribe exercise for a survivor of breast cancer, one should refer to the recommendations by the American College of Sports Medicine, American Cancer Society, and American Heart Association. These organizations along with the US Department of Health and Human Services recommend an overall volume of weekly activity of 150 minutes of moderate-intensity AE or 75 minutes of vigorous-intensity $\mathrm{AE}$, or an equivalent combination and 2-3 weekly strength training sessions including exercises for major muscle groups. ${ }^{13,92}$ These are recommendations for overall health and fitness improvements, and maintaining a healthy body weight should be considered when initiating or executing an exercise program for BCS.

\section{Conclusion}

Based on the current findings, exercise participation after cancer-related treatments elicits beneficial effects on physical 
and emotional well-being, lymphedema management, and maintenance of BMD in BCS. Large randomized controlled trials are necessary to determine whether exercise can reduce the risk of cancer recurrence in BCS. Participation in regular exercise, preferably both $\mathrm{AE}$ and RE modes, can alleviate some cancer treatment-related side effects and improve survivorship. Although the scientific knowledge supporting participation in exercise is profound, exercise adherence remains a challenge in $\mathrm{BCS}$. In future, health care-supported exercise programs for cancer survivors may be necessary, similar to cardiac rehabilitation exercise programs for cardiac patients, to promote a behavioral change to a more active lifestyle.

\section{Disclosure}

The authors report no conflicts of interest in this work.

\section{References}

1. American Cancer Society. What are the Key Statistics About Breast Cancer. 2015; Available from: http://www.cancer.org/cancer/breastcancer/ detailedguide/breast-cancer-key-statistics. Accessed April 26, 2015.

2. Holmes MD, Chen WY, Feskanich D, Kroenke CH, Colditz GA. Physical activity and survival after breast cancer diagnosis. JAMA. 2005;293(20):2479-2486.

3. Kruk J, Czerniak U. Physical activity and its relation to cancer risk: updating the evidence. Asian Pac J Cancer Prev. 2013;14(7):3993-4003.

4. MacVicar MG, Winningham ML, Nickel JL. Effects of aerobic interval training on cancer patients' functional capacity. Nurs Res. 1989;38(6):348-351.

5. Winningham ML, MacVicar MG, Bondoc M, Anderson JI, Minton JP. Effect of aerobic exercise on body weight and composition in patients with breast cancer on adjuvant chemotherapy. Oncol Nurs Forum. 1989;16(5):683-689.

6. Bernstein L, Henderson BE, Hanisch R, Sullivan-Halley J, Ross RK. Physical exercise and reduced risk of breast cancer in young women. J Natl Cancer Inst. 1994;86(18):1403-1408.

7. Carpenter CL, Ross RK, Paganini-Hill A, Bernstein L. Lifetime exercise activity and breast cancer risk among post-menopausal women. $\mathrm{Br} \mathrm{J}$ Cancer. 1999;80(11):1852-1858.

8. Patel AV, Callel EE, Bernstein L, Wu AH, Thun MJ. Recreational physical activity and risk of postmenopausal breast cancer in a large cohort of US women. Cancer Causes Control. 2003;14(6):519-529.

9. Kim CJ, Kang DH, Park JW. A meta-analysis of aerobic exercise interventions for women with breast cancer. West J Nurs Res. 2009; 31(4):437-461.

10. Courneya KS. Exercise in cancer survivors: and overview of research. Med Sci Sports Exerc. 2003;35(11):1846-1852.

11. Irwin ML, Crumley D, McTiernan A, et al. Physical activity levels before and after a diagnosis of breast carcinoma: the health, eating, activity, and lifestyle (HEAL) study. Cancer. 2003;97(7):1746-1757.

12. Jones LW, Eves ND, Haykowsky M, Freedland SJ, Mackey JR. Exercise intolerance in cancer and the role of exercise therapy to reverse dysfunction. Lancet Oncol. 2009;10(6):598-605.

13. Schmitz KH, Courneya KS, Matthews C, et al; American College of Sports Medicine. American College of Sports Medicine roundtable on exercise guidelines for cancer survivors. Med Sci Sports Exerc. 2010;42(7):1409-1426.

14. Schmitz KH, DiSipio T, Gordon LG, Haynes SC. Adverse breast cancer treatment effects: the economic case for making rehabilitative programs standard of care. Support Care Cancer. 2015;23(6):1807-1817.
15. Jones LW, Courneya KS, Mackey JR, et al. Cardiopulmonary function and age-related decline across the breast cancer survivorship continuum. J Clin Oncol. 2012;30(20):2530-2537.

16. Irwin ML, Alvarez-Reeves M, Cadmus L, et al. Exercise improves body fat, lean mass, and bone mass in breast cancer survivors. Obesity (Silver Spring). 2009;17(8):1534-1541.

17. Scott E, Daley AJ, Doll H, et al. Effects of an exercise and hypocaloric healthy eating program on biomarkers associated with long-term prognosis after early-stage breast cancer: a randomized controlled trial. Cancer Causes Control. 2013;24(1):181-191.

18. Campbell KL, Neil SE, Winter-Stone KM. Review of exercise studies in breast cancer survivors: attention to principles of exercise training. Br J Sports Med. 2012;46(13):909-916.

19. Saarto T, Sievänen H, Kellokumpu-Lehtinen P, et al. Effect of a supervised and home exercise training on bone mineral density among breast cancer patients. A 12-month randomised controlled trial. Osteoporos Int. 2011;23(5):1601-1612.

20. Brdareski Z, Djurovic A, Susnjar S, et al. Effects of a short-term differently dosed aerobic exercise on maximum aerobic capacity in breast cancer survivors: a pilot study. Vojnosanit Pregl. 2012;69(3): 237-242.

21. Guinan E, Hussey J, Broderick JM, et al. The effect of aerobic exercise on metabolic and inflammatory markers in breast cancer survivors - a pilot study. Support Care Cancer. 2013;21(7):1983-1992.

22. Cormie P, Galvao DA, Spry N, Joseph D, Taaffe DR, Newton RU. Functional benefits are sustained after a program of supervised resistance exercise in cancer patients with bone metastases: longitudinal results of a pilot study. Support Care Cancer. 2014;22(6):1537-1548.

23. Hardee JP, Porter RR, Sui X, et al. The effect of resistance exercise on all-cause mortality in cancer survivors. Mayo Clin Proc. 2014; 89(8):1108-1115.

24. Benton MJ, Schlairet MC, Gibson DR. Change in quality of life among breast cancer survivors after resistance training: is there an effect of age? J Aging Phys Act. 2014;22(2):178-185.

25. Winter-Stone KM, Dobek J, Bennett JA, Nail LM, Leo MC, Schwartz A. The effect of resistance training on muscle strength and physical function in older, postmenopausal breast cancer survivors: a randomized controlled trial. J Cancer Surviv. 2011;6(2):189-199.

26. Waltman NL, Twiss JJ, Ott CD, et al. The effect of weight training on bone mineral density and bone turnover in postmenopausal breast cancer survivors with bone loss: a 24-month randomized controlled trial. Osteoporos Int. 2010;21(8):1361-1369.

27. Milne HM, Wallman KE, Gordon S, Courneya KS. Effects of a combined aerobic and resistance exercise program in breast cancer survivors: a randomized controlled trial. Breast Cancer Res Treat. 2008;108(2):279-288.

28. Waltman NL, Twiss JJ, Ott CD, et al. Testing an intervention for preventing osteoporosis in postmenopausal breast cancer survivors. J Nurs Scholarsh. 2003;35(4):333-338.

29. Mills RC, Nascimento MG, de Melo GF, Hackney AC, Battaglini CL. Exercise training improves mean arterial pressure in breast cancer survivors. Motriz. 2014;30(3):325-331.

30. Heim ME, Malsburg ME, Niklas A. Randomized controlled trial of a structured training program in breast cancer patients with tumor-related chronic fatigue. Oncol Res Treat. 2007;30(8):8-9.

31. Costanzo ES, Lutgendorf SK, Mattes ML, et al. Adjusting to life after treatment: distress and quality of life following treatment for breast cancer. Br J Cancer. 2007;97(12):1625-1631.

32. Kroenke CH, Rosner B, Chen WY, Kawachi I, Colditz GA, Holmes MD. Functional impact of breast cancer by age at diagnosis. J Clin Oncol. 2004;22(10):1849-1856.

33. Jason L, Brown M, Evans M, et al. Measuring substantial reductions in functioning in patients with chronic fatigue syndrome. Disabil Rehabil. 2011;33(7):589-598.

34. Burgess C, Cornelius V, Love S, Graham J, Richards M, Ramirez A. Depression and anxiety in women with early breast cancer: five year observational cohort study. BMJ. 2005;330(7493):702. 
35. Kim SH, Son BH, Hwang SY, et al. Fatigue and depression in diseasefree breast cancer survivors: prevalence, correlates, and association with quality of life. J Pain Symptom Manage. 2008;35(6):644-655.

36. Hayes SC, Rye S, Disipio T, et al. Exercise for health: a randomized, controlled trial evaluating the impact of a pragmatic, translational exercise intervention on the quality of life, function and treatment-related side effects following breast cancer. Breast Cancer Res Treat. 2013; 137(1):175-186.

37. Cadmus LA, Salovey P, Yu H, Chung G, Kasl S, Irwin ML. Exercise and quality of life during and after treatment for breast cancer: results of two randomized controlled trials. Psychooncology. 2009;18(4): 343-352.

38. Fillion L, Gagnon P, Leblond F, et al. A brief intervention for fatigue management in breast cancer survivors. Cancer Nurs. 2008; 31(2):145-159.

39. Courneya KS, Mackey JR, Bell JG, Jones LW, Field CJ, Fairey AS. Randomized controlled trial of exercise training in postmenopausal breast cancer survivors: cardiopulmonary and quality of life outcomes. J Clin Oncol. 2003;33(10):1625-1631.

40. Midtgaard J, Rorth M, Stelter R, Adamsen L. The group matters: an explorative study of group cohesion and quality of life in cancer patients participating in physical exercise intervention during treatment. Eur $J$ Cancer Care. 2006;15(1):25-33.

41. Murtezani A, Ibraimi Z, Bakalli A, Krasniqi S, Disha ED, Kurtishi I. The effect of aerobic exercise on quality of life among breast cancer survivors: a randomized controlled trial. J Cancer Res Ther. 2014;10(3):658-664.

42. Mehnert A, Veers S, Howard D, Braumann K, Kock U, Schulz K. Effects of a physical exercise rehabilitation group program on anxiety, depression, body image, and health-related quality of life among breast cancer patients. Oncol Res Treat. 2011;34(5):248-253.

43. Rogers LQ, Courneya KS, Anton PM, et al. Effects of the BEAT cancer physical activity behavior change intervention on physical activity, aerobic fitness, and quality of life in breast cancer survivors: a multicenter randomized controlled trial. Breast Cancer Res Treat. 2015; 19(1):109-119.

44. Ohira T, Schmitz KH, Ahmed RL, Yee D. Effects of weight training on quality of life in recent breast cancer survivors: the weight training for breast cancer survivors (WTBS) study. Cancer. 2006; 106(9):2076-2083.

45. Spector D, Deal AM, Amos KD, Yang H, Battaglini CL. A pilot study of a home-based motivational exercise program for African American breast cancer survivors: clinical and quality of life outcomes. Integr Cancer Ther. 2014;13(2):121-132.

46. Sprod LK, Hsieh CC, Hayward R, Schneider CM. Three versus six months of exercise training in breast cancer survivors. Breast Cancer Res Treat. 2010;121(2):413-419.

47. Fu MR, Ridner SH, Armer J. Post-breast cancer. Lymphedema: part 1. Am J Nurs. 2009;109(7):48-54. quiz 55.

48. Cheville AL, McGarvey CL, Petrek JA, Russo SA, Thiadens SR, Taylor ME. The grading of lymphedema in oncology clinical trials. Semin Radiat Oncol. 2003;13(3):214-225.

49. Sayko O, Pezzin LE, Yen TW, Nattinger AB. Diagnosis and treatment of lymphedema after breast cancer: a population-based study. $P M R$. 2013;5(11):915-923.

50. Hayes SC, Janda M, Cornish B, Battistutta D, Newman B. Lymphedema after breast cancer: incidence, risk factors, and effect on upper body function. J Clin Oncol. 2008;26(21):3536-3542.

51. Norman SA, Localio AR, Potashnik SL, et al. Lymphedema in breast cancer survivors: incidence, degree, time course, treatment, and symptoms. J Clin Oncol. 2009;27(3):390-397.

52. Clark B, Sitzia J, Harlow W. Incidence and risk of arm oedema following treatment for breast cancer: a three-year follow-up study. QJM. 2005;98(5):343-348.

53. Geller BM, Vacek PM, O'Brien P, Secker-Walker RH. Factors associated with arm swelling after breast cancer surgery. $J$ Womens Health (Larchmt). 2003;12(9):921-930.
54. Ridner SH. The psycho-social impact of lymphedema. Lymphat Res Biol. 2009;7(2):109-112.

55. Ahmed RL, Prizment A, Lazovich D, Schmitz KH, Folsom AR. Lymphedema and quality of life in breast cancer survivors: the Iowa women's health study. J Clin Oncol. 2008;26(35):5689-5696.

56. International Society of Lymphology. The diagnosis and treatment of peripheral lymphedema. 2009 concensus document of the international society of lymphology. Lymphology. 2009;42(2):51-60.

57. National Lymphedema Network Medical Advisory Committee. Screening and Measurement for Early Detection of Breast Cancer Related Lymphedema; 2013. Available from: http://lymphnet.org/resources/ position-paper-screening-and-measurement-for-early-detection-ofbreast-cancer-related. Accessed May 7, 2015.

58. Kwan ML, Cohn JC, Armer JM, Stewart BR, Cormier JN. Exercise in patients with lymphedema: a systematic review of the contemporary literature. J Cancer Surviv. 2011;5(4):320-336.

59. Cheema B, Gaul CA, Lane K, Fiatarone Singh MA. Progressive resistance training in breast cancer: a systematic review of clinical trials. Breast Cancer Res Treat. 2008;109(1):9-26.

60. Ganz PA. The quality of life after breast cancer - solving the problem of lymphedema. N Engl J Med. 1999;340(5):383-385.

61. Rockson SG. Precipitating factors in lymphedema: myths and realities. Cancer. 1998;83(12 Suppl American):2814-2816.

62. Young-McCaughan S, Arzola SM. Exercise intervention research for patients with cancer on treatment. Semin Oncol Nurs. 2007; 23(4):264-274.

63. Sander AP, Wilson J, Izzo N, Mountford SA, Hayes KW. Factors that affect decisions about physical activity and exercise in survivors of breast cancer: a qualitative study. Phys Ther. 2012;92(4):525-536.

64. SchmitzKH,Ahmed RL, Troxel A, etal. Weight lifting in women with breastcancer-related lymphedema. N Engl J Med. 2009;361(7):664-673.

65. Cheema BS, Kilbreath SL, Fahey PP, Delaney GP, Atlantis E. Safety and efficacy of progressive resistance training in breast cancer: a systematic review and meta-analysis. Breast Cancer Res Treat. 2014; 148(2):249-268.

66. Winer EP, Hudis C, Burstein HJ, et al. American society of clinical oncology technology assessment on the use of aromatase inhibitors as adjuvant therapy for postmenopausal women with hormone receptor-positive breast cancer: status report 2004. J Clin Oncol. 2005;23(3):619-629.

67. Winter-Stone KM, Dobek J, Nail L, Leo MC, Naik A, Schwartz A. Strength training bone loss and builds muscle in postmenopausal breast cancer survivors: a randomized, controlled trial. Breast Cancer Res Treat. 2011;127(2):447-456.

68. Dobek J, Winters-Stone KM, Bennett JA, Nail L. Musculoskeletal changes after 1 year of exercise in older breast cancer survivors. J Cancer Surviv. 2014;8(2):304-311.

69. Bruning PF, Pit MJ, de Jong-Bakker M, van den Ende A, Hart A, van Enk A. Bone mineral density after adjuvant chemotherapy for premenopausal breast cancer. Br J Cancer. 1990;61(2):308-310.

70. Eastell R, Adams JE, Coleman RE, et al. Effect of anastrozole on bone mineral density: 5-year results from the anastrozole, tamoxifen, alone or in combination trial 18233230. J Clin Oncol. 2008;26(7):1051-1057.

71. Cameron DA, Douglas S, Brown JE, Anderson RA. Bone mineral density loss during adjuvant chemotherapy in pre-menopausal women with early breast cancer: is it dependent on oestrogen deficiency? Breast Cancer Res Treat. 2010;123(3):805-814.

72. Turner $\mathrm{CH}$, Robling AG. Mechanisms by which exercise improves bone strength. J Bone Miner Metab. 2005;23(1):16-22.

73. Winters-Stone KM, Dobek J, Nail LM, et al. Impact + resistance training improves bone health and body composition in prematurely menopausal breast cancer survivors: a randomized controlled trial. Osteoporos Int. 2013;24(5):1637-1646.

74. Chlebowski RT. Nutrition and physical activity influence on breast cancer incidence and outcome. Breast. 2013;22(Suppl 2):S30-S37.

75. Irwin ML, Smith AW, McTiernan A, et al. Influence of pre- and postdiagnosis physical activity on mortality in breast cancer survivors: the health, eating, activity, and lifestyle study. J Clin Oncol. 2008; 26(24):3958-3964. 
76. Pierce JP, Stefanick ML, Flatt SW, et al. Greater survival after breast cancer in physically active women with high vegetable-fruit intake regardless of obesity. J Clin Oncol. 2007;25(17):2345-2351.

77. West-Wright CN, Henderson KD, Sullivan-Halley J, et al. Physical activity and survival after diagnosis of invasive breast cancer. Cancer Epidemiol Biomarkers Prev. 2008;17(2):379-386.

78. Chen X, Lu W, Zheng W, et al. Exercise after diagnosis of breast cancer in association with survival. Cancer Prev Res (Phila). 2011; 4(9):1409-1418.

79. Irwin ML, McTiernan A, Manson JE, et al. Physical activity and survival in postmenopausal women with breast cancer: results from the women's health initiative. Cancer Prev Res (Phila). 2011;4(4):522-529.

80. Ibrahim EM, Al-Homaidh A. Physical activity and survival after breast cancer diagnosis: meta-analysis of published studies. Med Oncol. 2011; 28(3):753-765.

81. Schmitz KH. Exercise for secondary prevention of breast cancer: moving from evidence to changing clinical practice. Cancer Prev Res (Phila). 2011;4(4):476-480.

82. Courneya KS, Segal RJ, McKenzie DC, et al. Effects of exercise during adjuvant chemotherapy on breast cancer outcomes. Med Sci Sports Exerc. 2014;46(9):1744-1751.

83. Ulrich CM, Wiskemann J, Steindorf K. [Physiologic and molecular mechanisms linking physical activity to cancer risk and progression]. Bundesgesundheitsblatt Gesundheitsforschung Gesundheitsschutz. Health Research. 2012;55(1):3-9.

84. McTiernan A, Tworoger SS, Ulrich CM, et al. Effect of exercise on serum estrogens in postmenopausal women: a 12-month randomized clinical trial. Cancer Res. 2004;64(8):2923-2928.

85. McTiernan A, Tworoger SS, Rajan KB, et al. Effect of exercise on serum androgens in postmenopausal women: a 12-month randomized clinical trial. Cancer Epidemiol Biomarkers Prev. 2004;13(7):1099-1105.
86. Irwin ML, Varma K, Alvarez-Reeves M, et al. Randomized controlled trial of aerobic exercise on insulin and insulin-like growth factors in breast cancer survivors: the Yale exercise and survivorship study. Cancer Epidemiol Biomarkers Prev. 2009;18(1):306-313.

87. Chlebowski RT, Pettinger M, Stefanick ML, Howard BV, MossavarRahmani Y, McTiernan A. Insulin, physical activity, and caloric intake in postmenopausal women: breast cancer implications. J Clin Oncol. 2004;22(22):4507-4513.

88. McTiernan A, Rajan KB, Tworoger SS, et al. Adiposity and sex hormones in postmenopausal breast cancer survivors. J Clin Oncol. 2003; 21(10):1961-1966.

89. Pierce BL, Neuhouser ML, Wener MH, et al. Correlates of circulating $\mathrm{C}$-reactive protein and serum amyloid A concentrations in breast cancer survivors. Breast Cancer Res Treat. 2009;114(1):155-167.

90. Goodwin PJ, Boyd NF. Body size and breast cancer prognosis: a critical review of the evidence. Breast Cancer Res Treat. 1990; 16(3):205-214.

91. Demark-Wahnefried W, Platz EA, Ligibel JA, et al. The role of obesity in cancer survival and recurrence. Cancer Epidemiol Biomarkers Prev. 2012;21(8):1244-1259.

92. Haskell WL, Lee IM, Pate RR, et al; American College of Sports Medicine, American Heart Association. Physical activity and public health: updated recommendation for adults from the American College of Sports Medicine and the American Heart Association. Circulation. 2007;116(9):1081-1093.

93. Baumann FT, Bloch W, Weissen A, et al. Physical activity in breast cancer patients during medical treatment and in the aftercare-a review. Breast Care (Basel). 2013;8(5):330-334.

94. Jones LW, Alfano CM. Exercise-oncology research: past, present, and future. Acta Oncol. 2013;52(2):195-215.
Breast Cancer: Targets and Therapy

\section{Publish your work in this journal}

Breast Cancer: Targets and Therapy is an international, peerreviewed open access journal focusing on breast cancer research, identification of therapeutic targets and the optimal use of preventative and integrated treatment interventions to achieve improved outcomes, enhanced survival and quality of life for the cancer patient.

\section{Dovepress}

View the full aims and scopes of this journal here. The manuscript management system is completely online and includes a very quick and fair peer-review system, which is all easy to use. Visit http:// www.dovepress.com/testimonials.php to read real quotes from published authors. 